\title{
The Wall and the Arcade: Walter Benjamin's Metaphysics of Translation and its Affiliates
}

SANDBAnK, SHIMON. 2019. The Wall and the Arcade: Walter Benjamin's Metaphysics of Translation and its Affiliates. Brighton, Chicago \& Toronto: Sussex Academic Press.

Reviewed by VIVEK KUMAR

Walter Benjamin remains a towering figure in the realm of Translation Studies with his unexpected and extremely philosophical insights offered in his seminal essay "The Translator's Task". He bats for a translation which thrives on the idea of translation as a means and not an end in itself in the process of attaining the ultimate "pure language". Benjamin is not at all concerned with the reader and the deliverance of an equivalent meaning through the process of translation. In The Wall and the Arcade, Shimon Sandbank delves deeper into Walter Benjamin's theory of translation also due to the disparity she finds in Benjamin's theory and practice in his translations of Baudelaire. The book is divided into twelve chapters out of which the first five chapters deal with the metaphysical aspects of Benjamin's theory. In the rest of the chapters Shimon compares and contrasts Benjamin's theory with other works and thinkers.

In the first chapter titled, "No Reader" Shimon remarks upon the irrelevance of the reader as proclaimed by Walter Benjamin, wherein he says that the work translated is not intended for the reader, but serves a higher purpose. Shimon finds a justification of Benjamin's idea in his faith in the Kabbalistic language mysticism where language is elevated to a divine pedestal, thereby removing it from the concerns of the mortal world. Benjamin is opposed to what he considers the "bourgeois" theory of language which advocated for the arbitrariness of the linguistic sign. Translation, therefore, for Benjamin, becomes an act of transformation of language from 
the realm of the divine to that of the humankind and its return to the divine in its complete pure form. The Task of the Translator therefore is to contribute his bit in the grand scheme of the things in order to unite language with the creator.

The second chapter, "Inessential meaning" further discusses the elevation of language to a divine status which in turn all but removes the reader and hence the need for reproduction of meaning from the original text. His theory of translation appears to originate from the Jewish Kabbala and "the mystical paradigm of the history of language". The translator's task, therefore, is the translation of the "inexpressible residue of God's word'. With the relevance of meaning rendered inessential by the divine origin of language, the idea of equivalence in translation remains moot. Shimon illustrates Benjamin's advocacy for translation as an instrument to attain the ultimate Adamic language in the next chapter. Benjamin does not intend a translation to be "an equivalent copy of the original's meaning" but wants the original to transcend into "a linguistic sphere that is both higher and purer". Here, Shimon quotes Benjamin's simile for his concept of translation of that of a broken vessel with translation's not resembling the sense of the original but fashioning themselves in a correspondence of their counterparts in an attempt to see them fit together as fragments of a vessel constituting a higher form of language.

The next radical idea Benjamin propounds, according to Shimon, is the breaking through the structural constraints of the language. Fidelity in translation makes the reader rest instead of providing him encouragement to "complete" it. Benjamin advocates for a translation which "conveys the syntax word-for-word". He is of the opinion that word with its syntactic position is all what counts and not the entire sentence. Shimon explains the phenomenon of poetry gaining from translations by taking a dip into the historical contexts of 
Roman imperialism where translation was considered an instrument in the ultimate colonization of a land.

Shimon explains further that the way out for a translator is to "follow rules other than that of equivalent sense in his quest for advancing towards "Pure Language". The author tries to explain the idea of Pure Language in translation by quoting Schopenhauer who suggested that the idea from the original text should be dissolved into its most basic components and then reconstructed in the new language. For Benjamin "Pure Language is the meaningless absolute of the divine revelation". The shift in the attitude of Benjamin for the process of reproduction of art is emphasised by the author, the later Benjamin (after his conversion to Marxism) in his essay "The Work of Art in the Age of Mechanical Reproduction", seems to exempt the process from theological categories. The loss of Aura due to an artwork's closeness and usefulness rather than distance and uniqueness is considered a virtue of and not a fall into an "abyss of prattle". Shimon Sandbrook compares and contrasts Rosenzweig's and Benjamin's theories of translation. Both of them seem to agree on the idea that language and the world are one and "language constitutes the reality it designates". Translation, for Benjamin is motivated by a return to the mythic past and to the Adamic language, in which word is identical with thing, not its arbitrary sign, for Rosenzweig it is meant for human beings and his experience of dialogue with God. Rosenzweig is more democratic in his approach as he considers the reader to be the very life of the work of art, which is in sharp contrast with Benjamin's view that doesn't deem it necessary to acknowledge the reader. The basic common denominator to both these theorists is the idea of "essential unity of all languages" except that "the commandment of universal human communication based on that unity sets the former radically apart from the latter". Rosenzweig's theory deals more with the concrete aspects of 
poetry translation than Walter Benjamin, hence it appears to be more useful.

Shimon Sandbrook cites Derrida as a counter viewpoint to that of Benjamin, for Derrida Adamic Language does not exist and "it is a fictitious projection of the desperate need to escape the "text" that is our only home. Derrida is a strident opposer of the idea of pure language and purity itself, as these ideas do not stand their ground to the deconstructive viewpoints. Derrida and Benjamin are similar in the sense that both Derrida's language-of-one's-own and Benjamin's Pure Language theories are utopian and are deemed to be unattainable. In the last chapter -The Practical Dimension, Shimon Sandbank discusses the practical applications of Benjamin's theories; she discards the myth of pure language categorically. But she regards the syntactic literalness and the idea of "transformation of the target language rather than its imposition on the original" to be Benjamin's major contribution to the field of Translation Studies. This short book of about hundred pages is aimed at simplifying Walter Benjamin's highly philosophical theory of translation. The author, a translator herself takes up Walter Benjamin's theory as she finds Benjamin's theory to be dissenting and highly unexpected and different from what Benjamin himself practices in his translations of Baudelaire. Though this book is intended to be a simplified and lucid rendering of Walter Benjamin's theory, the highly philosophical insights however simplified seems to offer very less to someone from a nonacademic background. The limited audience garnered by the book remain a few translation studies academics.

$$
* * *
$$

Cite this work: Kumar, Vivek. 2020. The Wall and the Arcade: Walter Benjamin's Metaphysics of Translation and its Affiliates. Review of The Wall and the Arcade: Walter Benjamin's Metaphysics of Translation and its Affiliates, by Shimon Sandbrook. Translation Today, Vol. 14(1). 135-138.

DOI: $10.46623 / \mathrm{tt} / 2020.14$.1.br3 